\title{
AN INNOVATIVE TRAINING OF PRODUCTION PLANNERS THROUGH VIRTUAL PRODUCTION PERFORMING
}

\author{
Mihael Debevec, Miha Pipan, Hugo Zupan, Niko Herakovic
}

Original scientific paper

Nowadays the production process with as few as possible deadlocks is the most important goal of management in every company. An optimized production process can be reached with well-trained personnel and especially with well-trained schedule planners. In this contribution, a new strategy on how to train production planners for different types of production by using virtual factory is presented. Also, two specially developed parametric simulation models for typical make-to-order and large-scale types of production are presented. Every model describes the real production process in detail so that it enables the observation of responses to the different input data. In the first step, the strategy covers the training of personnel so that they learn how varied input data reflect in the output results. The second strategy step is supporting schedule planning by using virtual factory where variants of schedule plans are tested much earlier than the real production process is performed.

Keywords: modelling; optimization; simulation; schedule plan; training; virtual factory

Inovativna obuka za planere proizvodnje kroz odvijanje virtualne proizvodnje

Izvorni znanstveni članak

Danas je proces proizvodnje s najmanje zastoja najvažniji cilj upravljanja u svakom poduzeću. Optimizirani proces proizvodnje može se postići s dobro obučenim osobljem i osobito s dobro obučenim planerima proizvodnje. U ovom članku predstavljena je nova strategija treniranja planera proizvodnje za više tipova proizvodnje uz korištenje virtualne tvornice. Također su prikazana dva posebno razvijena parametarska simulacijska modela za tipične vrste pojedinačne i velikoserijske proizvodnje. Svaki model opisuje stvarni proizvodni proces u detalje i tako omogućuje promatranje odgovora na različite ulazne podatke. U prvom koraku ova strategija obuhvaća obuku osoblja, da nauče kako se različiti ulazni podaci odražavaju u izlaznim rezultatima. Drugi korak ove strategije je podupiranje planiranja proizvodnje uz pomoć virtualne tvornice, u kojoj se varijante proizvodnog plana testiraju mnogo ranije nego što se realni proizvodni proces odvije.

Ključne riječi: modeliranje; obuka; optimizacija; plan proizvodnje; simulacija; virtualna tvornica

\section{Introduction}

Nowadays, modern manufacturing environment requires trained personnel who must respond actively to different disturbances in the production process. For this reason, companies need modern and innovative tools to educate and train employees and prepare them as much as possible for situations where circumstances change and disturbances occur in the manufacturing process. Training should be performed in a dynamic production environment by using computers to build production process models and then performing different simulations. Traditional learning approaches do not enable that sort of training. Also, such tools are useful for education of students, so that after graduating, they are ready for effective and autonomous planning of production processes.

In the existing research, a number of useful examples are presented $[1 \div 14]$ which are usable for training in specialized areas. Furthermore, a number of studies have been made and different models developed in other areas with the aim to optimize the existing processes, and these solutions can also be used for training or education purposes $[15 \div 31]$.

Our research work has proven that virtual factory (VF) $[32 \div 37]$ is a very useful tool for the training of the planners of production processes. A major advantage of the concept is that the VF does not consume any material, resources or energy - we operate only with data. During the training process, the real production process is not interrupted and consequently the equipment is not occupied and cannot be damaged. The use of the VF is suitable for the designing of new production systems or to improve the existing ones.

Based on the findings and our own research, we developed two concepts and models that are useful for the training for different levels of production.

\section{The basics of virtual factory}

A virtual production in a VF is defined as the integration of different models, simulations and presentation techniques in an integrated system in a computer. It allows the execution of the production or schedule plan in a virtual environment or, in other words, the performing of the production process in a VF $[35,37]$. Just like for a real factory, it is considered that one of the most important parts in the VF is the resource management.

In the field of the production processes, research is generally oriented in a few specialized directions. The first direction is the scheduling of the production operations in time scale $[1,22,27,38,39]$, and that is the most frequently addressed issue in practice. The second area is focused on the improvement of the production process at the level of the performing of operations $[3,16$, $17,21,32]$. To the third area belong some special principles to improve the efficiency of the production process $[4,6 \div 8,12 \div 14,18 \div 20,23 \div 30,40 \div 42]$. The fourth area is oriented towards savings and better economical acceptance. In this area, there can be found several studies about reducing the costs and reducing power consumption [9, 15, 28, 29, 39, 43].

For the development of the concepts and models for training, the researchers have been focused on the 
improvement of the production process at the level of the performing of operations.

\section{INPUTS}

\begin{tabular}{l} 
Schedule (production) plan \\
Machining part or parts \\
Resources \\
Energy \\
\hline
\end{tabular}

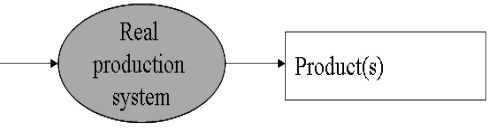

\section{Schedule (production) plan} Data about machining part or parts Data about resources

Data about energy

\section{Figure 1 The basic principle of the virtual factory}

For both concepts and models of the production processes, logical models were designed in the first step, and they were created based on the fundamental principle of the VF (Fig. 1), the theoretical assumptions [10, 11, $34 \div 37$ ] and the recent results of our research work [32]. VF consists of two basic parts: a virtual physical subsystem (VPS) and a real information subsystem (RIS). The virtual physical subsystem describes the logical dependencies between processes, material flow and the flow of resources in the production system [32]. For the real information subsystem, the existing information system of the production system is taken into account where the data flow is controlled by the integral information system. So the RIS covers the appropriate data structure that is needed to control the physical part of the VF. Relevant connections are established between the VPS and RIS to ensure the correct functioning of the VF.

Then, computer simulation models were designed on the basis of the logical models of the production process, and also the appropriate input and output data structures were created. The basic and main objective of the research was the creation of the virtual factory which enables and ensures the execution of a schedule plan in the same way as it is carried out in the real production process (Fig. 1).This means that all logical dependencies, which are characteristic of a real production system, are described in detail in the developed model, i.e. virtual factory.

In order to make the models easy for use, both simulation models of the production process were built in the standard programming tool Tecnomatix Plant Simulation [44] for several important reasons and advantages [45]:

- the simulation tool is standard and generally applicable,

- the tool is based on discrete events execution,

- the program is object-oriented,

- complex logical dependencies from the production system can be modelled through programming in the programming language SimTalk [46],

- data exchanges between the simulation model and databases are relatively easy to establish,

- the tool enables an easy way to create different graphical or numerical presentations about the progress of the production process in the virtual factory.
In VF, it is assumed that the energy for the operating of the production system is always available. Otherwise, the manufacturing process cannot be carried out.

\section{Simulation models for training}

For the purposes of educating and training employees or students, two models of the VF were developed for different types of production, based on the rules of the real production systems:

- $\quad$ the model for a make-to-order production (MOP) and

- the model for a large-scale type of production (LSTP).

\subsection{Model for a make-to-order production}

The concept for the model of a make-to-order production treats the operation as the elementary unit of the production process. The concept includes a logical rule that states that the performing of an operation can be started only when all the required resources, the data sets and the materials are available and present at the place where the planned operation will be performed. And the sequence of operations represents the production process (Fig. 2).

In the production process model for a MOP, first the data for the production process and then the presence of resources has been taken into account because due to the unavailability of resources deadlocks frequently occur. Among the most important resources are the transportation equipment, clamping equipment, cutting tools, measuring devices, machining centres, special tools and equipment, and human resources.

Based on the logical model (Fig. 2), a simulation model of the production process for a MOP was constructed in the computer environment Tecnomatix Plant Simulation (Fig. 3).

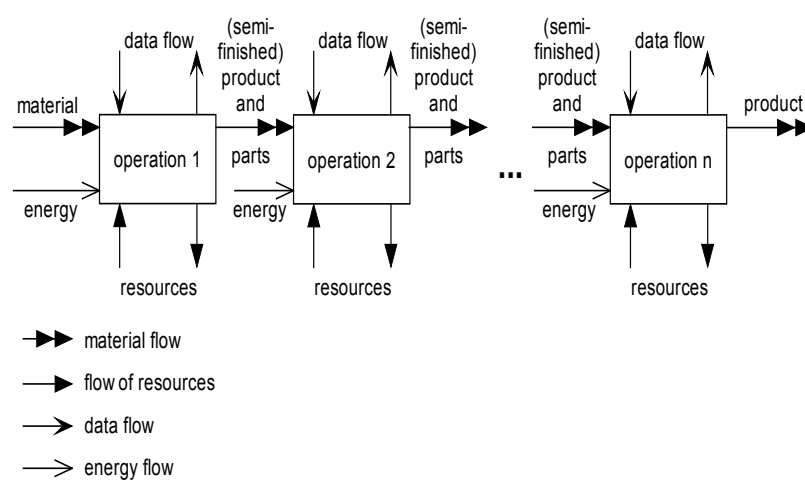

Figure 2 The logical scheme of the simulation model for a make-toorder production

The model is parametric so that the user inserts into the model the input data that is intended for the real production process for the observed period. Among the input data is the schedule plan, the list of available resources, work calendar and the number of available workers (Tab. 1). After the initial setup, the user performs a simulation for the desired observation period or for the production of the desired number of pieces. During the execution of the simulation, the speed of the simulation execution can be set to stepless, the simulation can be 
carried out step by step or it can be stopped at any time. The start date and time of every individual simulation run can be set to an arbitrary time. It is also possible to configure the production parameters for each production process.

Table 1 Important logical elements in the simulation model for a MOP

\begin{tabular}{|c|c|}
\hline Icon on Fig. 3 & Description \\
\hline$\frac{\text { 闻国 }}{\text { TT_1str }}$ & $\begin{array}{l}\text { table type objects: } \\
\text { TT_1str: the table with input data }- \text { schedule } \\
\text { data } \\
\text { TabSredst: the table with data about } \\
\text { resources } \\
\text { TabTermin_IZHODNA: the table with output } \\
\text { data - the results of the simulation }\end{array}$ \\
\hline EventControler & $\begin{array}{l}\text { EventController is the object for controlling } \\
\text { the simulation process }\end{array}$ \\
\hline 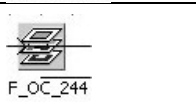 & $\begin{array}{l}\text { process type object: } \\
\text { F_OC_244 ... 282: objects that represent } \\
\text { machining centres }\end{array}$ \\
\hline$\prod_{\text {ZAS_DC1 }}$ & $\begin{array}{l}\text { objects of the chart type are used to display } \\
\text { the efficiency of a production unit }\end{array}$ \\
\hline Shiftcalendar & $\begin{array}{l}\text { the object of the ShiftCalendar type is used to } \\
\text { manage the working calendar and shifts }\end{array}$ \\
\hline $\begin{array}{ll}00 \\
\text { Workerpool }\end{array}$ & $\begin{array}{l}\text { the object of the WorkerPool type is used to } \\
\text { manage workers }\end{array}$ \\
\hline$M$ & $\begin{array}{l}\text { the object of the Method type contains } \\
\text { programs for the logical actions execution }\end{array}$ \\
\hline
\end{tabular}

In the presented model, there are pre-designed indicators for real-time tracking of the number of the finished parts, the consumed production time and the occupancy analysis of individual resources. The indicators can be displayed in text format on the screen or structured in table form. With simple additions, any indicator can be installed or any calculation and analysis can be performed online.

A set of input data contains information about the sequence of operations in the production process and a list of required resources that are necessary to perform every individual operation.

The output or acquired data from the simulation for every individual operation cover the start time of the operation execution, the end time of the operation execution and the anticipated duration of the operation execution.

In the execution of the simulation, the user can either choose the starting date or observe the output of the production process after a specified number of calendar days.

The MOP model has been tested and verified using known data from a company for an already performed production process, so that the input data and results of the production process were well known. To prove the adequacy of the model several testing simulation runs were carried out, and the acquired data showed that the developed model satisfactorily describes the real production process.

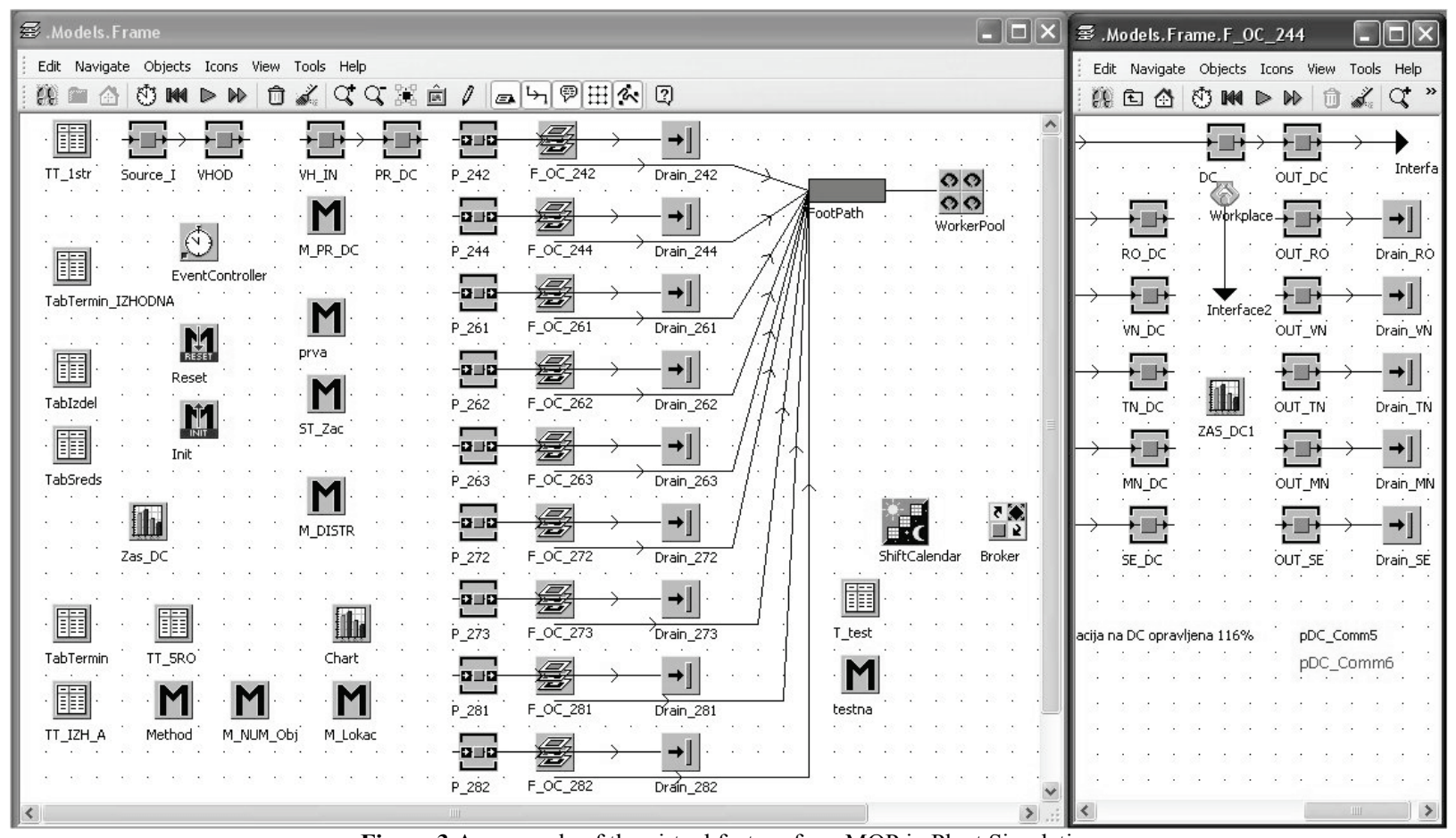

Figure 3 An example of the virtual factory for a MOP in Plant Simulation

\subsection{Model for a large-scale type of production}

In the concept for a large-scale type of production, the assembly or production cell is treated as the elementary unit of the production process, and in the model, the unit is treated as a submodel (Fig. 4). The model is developed as parametric in a way that it allows the setting of the production process parameters which depend on the product type.

In the production process model for a LSTP, the efficiency of production units plays an important role. This means that the amount of produced units per production time is significant. Inefficiency of production units occurs as a consequence of scheduled maintenance, parameters setting, calibrating, insufficient quantities of 
materials, full intermediate storages and unscheduled stoppages or failures.

The second purpose of the development of the model is real-time monitoring of stock in intermediate storages. Stock should not exceed the maximum capacity of the storages so that the production process does not stop.

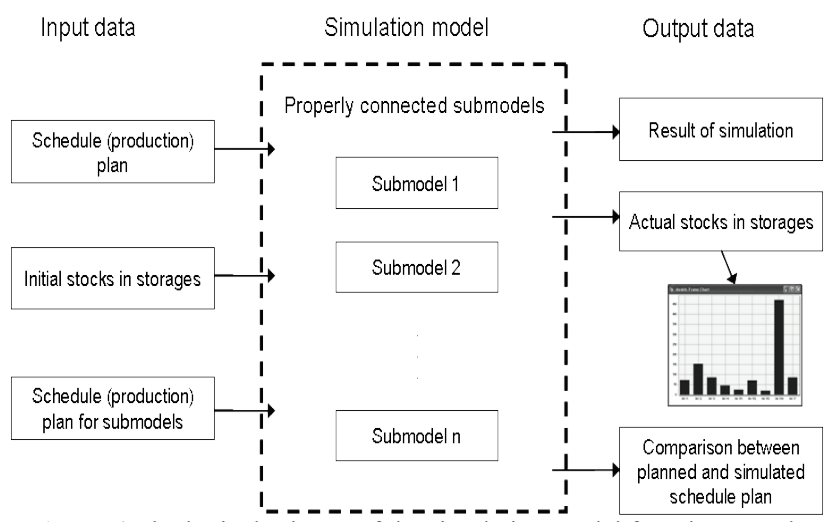

Figure 4 The logical scheme of the simulation model for a large-scale type of production

Based on the logical model (Fig. 4), a simulation model of the production process for a LSTP was constructed in the computer environment Tecnomatix Plant Simulation (Fig. 5).
In the model, the limitations are the same as in the real system: the number of workstations, the dimensions of the transport equipment between workstations and the capacity of intermediate storages. Just like in the real system, the sequence of working operations, schedule plan, work calendar, initial stocks and times for the rearrangement of work processes can be changed in the model, while the processing time of work processes adjusts automatically depending on the type of the product. This is performed through the use of advanced algorithms.

The model is parametric, so that the user inserts into the model the input data which is aimed for the real production process for the observed period. Among the input data is the main schedule plan, the schedule plan for all submodels, the value of the initial stock in intermediate storages, and the work calendar (Table 2). A simulation for the desired observation period or for the production of the desired number of pieces can be performed after the initial setup of the model. The user has the option to set the speed of the simulation execution to stepless; but the simulation can also be executed step by step or stopped at any time. He also has the option to configure the production parameters for each production process in the model.

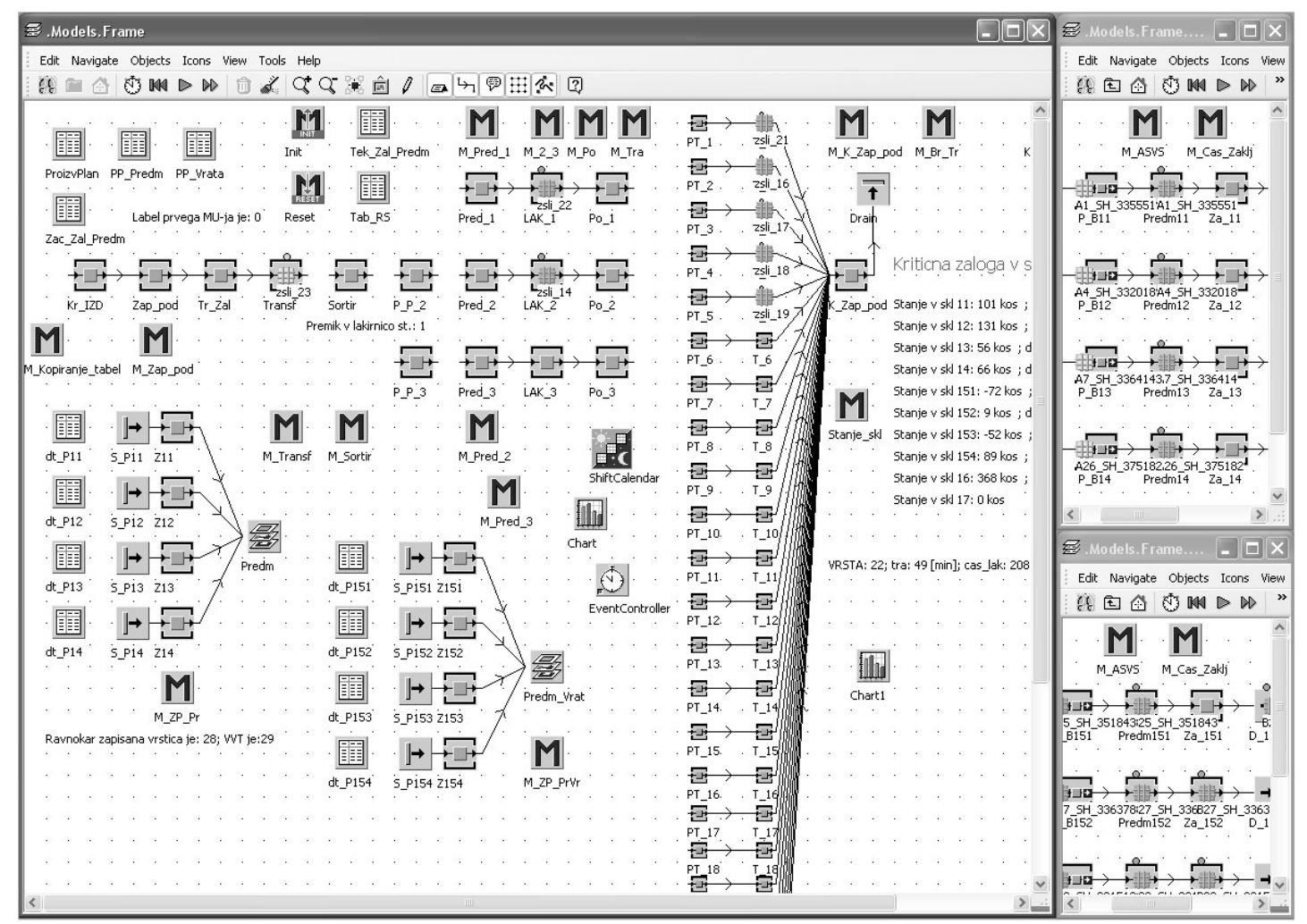

Figure 5 An example of a virtual factory for a LSTP in Plant Simulation

In the described model, the indicators are predesigned which enables real-time tracking of the number of finished parts in intermediate storages, the consumed production time and the occupancy analysis of the individual production place. The indicators can be displayed directly on the screen in text format or in charts or can be structured in table form. With simple additions, any indicator can be installed in the model or any calculation and analysis can be performed online.

Input data comprise the data about the sequence of batches of production on the production line. In this case, every batch represents the number of identical pieces in the series.

The output or acquired data from the simulation for each batch cover the start time of the production 
execution, the completion time of the production execution, the expected duration of the production execution and the time spent to produce one piece in a batch.

As with the MOP model, the user can either choose the starting date for performing the simulations or observe the production process for a specified number of calendar days.

Table 2 Important logical elements in the simulation model for a LSTP

\begin{tabular}{|c|c|}
\hline Icon on Fig. 5 & Description \\
\hline P & $\begin{array}{l}\text { table type objects: } \\
\text { ProizvPlan: the table with input data - } \\
\text { schedule data } \\
\text { PP_Predm, PP_Vrata: the table with input } \\
\text { data for submodels - schedule data } \\
\text { ZacZal_Predm: the table with data about } \\
\text { initial stock } \\
\text { TabRS: the table with output data - the } \\
\text { results of the simulation }\end{array}$ \\
\hline EventController & $\begin{array}{l}\text { EventController is the object for controlling } \\
\text { the simulation process }\end{array}$ \\
\hline iAK_ & $\begin{array}{l}\text { process type object: } \\
\text { LAK_1 . ... 3: objects that represent working } \\
\text { processes }\end{array}$ \\
\hline chart & $\begin{array}{l}\text { objects of the chart type are used to display } \\
\text { the value of stock in storages }\end{array}$ \\
\hline$\underset{\text { shiftcalendar }}{\text { s. }}$ & $\begin{array}{l}\text { the object of the ShiftCalendar type is used } \\
\text { to manage the working calendar and shifts }\end{array}$ \\
\hline$M$ & $\begin{array}{l}\text { the object of the Method type contains } \\
\text { programs for the logical actions executing }\end{array}$ \\
\hline
\end{tabular}

In the simulation model, a special chart is designed (Fig. 6) in which the actual state of the stock in intermediate storages is plotted. This allows the user to continuously monitor stock movements and compare the values with the maximum capacity of intermediate storages.

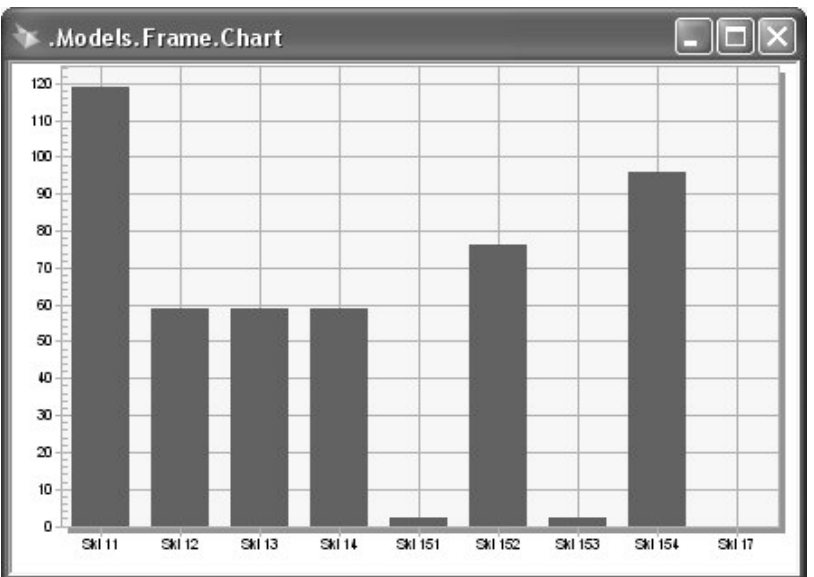

Figure 6 An example of the chart used for monitoring the values of stock in intermediate storages

The LSTP model has been tested and verified using known data from a company for an already performed production process. That way the input data and results of the production process were well known. To prove the adequacy of the model several testing simulation runs were carried out. The acquired data proved that the developed model satisfactorily describes the real production process.

\section{Conclusion}

The use of both models of the virtual factory for the purposes of training or education brings a number of advantages. The first advantage is obtaining the simulation results about the estimated execution of the schedule plan quickly. Testing has proven that the execution of a production process in the virtual factory for an entire work shift takes only a few minutes. Furthermore, with the testing of production plans in a virtual factory we do not intervene in the real production system and thereby we do not cause any disturbances. Because of this, we have practically unlimited possibilities of testing different schedule plans where we observe the behaviour of the production system as a function of time for an individual plan, or only observe the outputs of the production system. The models of production processes are designed parametrically, so for the purposes of training, we can easily test different production plans as input data. The developed models are user-friendly so that the user inserts into the model the input data, sets the process parameters, performs the simulation and evaluates the results of the simulation.

Users can perform a simulation for an existing or known production system where they can observe the outputs of the model according to different rearrangements in the virtual factory. By using the simulation, they can also study a planned production system where they test various configurations of the production system, or test the response of the planned system to different settings, among which we included the working calendar, number of shifts, different break times, number of employees, number of machines, variants of parallel processes, different process times, transport times, different transport routes and manners and transport strategy for components. Based on the different settings and acquired responses the users can determine the optimum production parameters.

The presented models have proven to be very useful for the training of employees who are dealing with the planning of the production process, as well as for the training of production engineering students at technical universities. Additionally, the virtual factories for a MOP and a LSTP have proven to be a useful tool with the help of which students obtain the experience of how the production system responds to different input data and settings.

Our plan for future research is oriented in two directions. In the first direction, we want to develop individual models to the level where all process parameters will be entered into a table, and on the basis of these data and via the advanced adaptive algorithms the parameters in the model will be set automatically. In the second direction, we want to develop advanced simulation models for other types of production.

\section{References}

[1] Cvetic,B.; Vasiljevic, D.; Mijatovic, I. Design and Application of a Decision Support Tool for the Selection of Logistics and Supply Chain Management Games. // International Journal of Engineering Education. 29, 6(2013), pp. 1527-1536. 
[2] Senk, I.; Ostojic, G.; Jovanovic, V.; Tarjan, L.; Stankovski, S. Experiences in Developing Labs for a Supervisory Control and Data Acquisition Course for Undergraduate Mechatronics Education. // Computer Applications in Engineering Education. 23, 1(2015), pp. 54-62. DOl: 10.1002/cae. 21578

[3] Padhi, S. S.; Wagner, S. M.; Niranjan, T. T.; Aggarwal, V. A simulation-based methodology to analyse production line disruptions. // International Journal of Production Research. 51, 6(2013), pp. 1885-1897. DOl: 10.1080/00207543.2012.720389

[4] Kostic, Z.; Cvetkovic, D.; Jevremovic, A.; Radakovic, D.; Popovic, R.; Markovic, D. The development of assembly constraints within a virtual laboratory for collaborative learning in industrial design. // Technical Gazette. 20, 5(2013), pp. 747-753.

[5] Berlec, T.; Kusar, J.; Rihar, L.; Starbek, M. Selecting of the most adaptable work equipment. // Journal of Mechanical Engineering. 59, 6(2013), pp. 400-408. DOI: 10.5545/svjme.2013.959

[6] Helleno, A. L.; Simon, A. T.; Papa, M. C. O.; Ceglio, W. E.; Rossa Neto, A. S.; Mourad, R. B. A. Integration University-Industry: Laboratory Model for Learning Lean Manufacturing Concepts in the Academic and Industrial Environments. // International Journal of Engineering Education. 29, 6(2013), pp. 1387-1399.

[7] Akkoyun, O.; Careddu, N. Mine simulation for educational purposes: A case study. // Computer Applications in Engineering Education. 23, (2015), pp. 286-293. DOI: 10.1002/cae.21598

[8] Uzam, M.; Li, Z. On an iterative deadlock prevention approach for automated manufacturing systems. // The International Journal of Advanced Manufacturing Technology. 74, 1-4(2014), pp. 503-507.

[9] Kreter, S.; Rieck, J.; Zimmermann, J. The total adjustment cost problem: Applications, models, and solution algorithms. // Journal of Scheduling. 17, 2(2014), pp. 145160. DOI: $10.1007 / \mathrm{s} 10951-013-0344-y$

[10] Mavrikios, D.; Papakostas, N.; Mourtzis, D.; Chryssolouris, G. On industrial learning and training for the factories of the future: a conceptual, cognitive and technology framework. // Journal of Intelligent Manufacturing. 24, 3(2013), pp. 473-485. DOI: 10.1007/s10845-011-0590-9

[11] Negahban, A.; Smith, J. S. Simulation for manufacturing system design and operation: Literature review and analysis. // Journal of Manufacturing Systems. 33, 2(2014), pp. 241-261. DOI: 10.1016/j.jmsy.2013.12.007

[12] Doltsinis, S. C.; Ratchev, S.; Lohse,N. A framework for performance measurement during production ramp-up of assembly stations. //European Journal of Operational Research. 229, 1(2013), pp. 85-94. DOI: 10.1016/j.ejor.2013.02.051

[13] Jovanovic, V.; Lei, M.; Guerra-Zubiaga, D.; Tomovic, M. M.Early Problems Identification in Collaborative Engineering with Different Product Data Modelling Standards. // International Journal of Computer Integrated Manufacturing. $\quad 28, \quad 11(2015)$, pp. 1155-1166. DOl: 10.1080/0951192X.2014.961961

[14] Iacob, R.; Popescu, D. Generation of disassembly directions based on component mobility. // Studies in Informatics and Control.22, 4(2013), pp. 307-318.

[15] Gracanin,D.; Lalic, B.; Beker, I.; Lalic, D.; Buchmeister, B. Cost-Time Profile Simulation for Job Shop Scheduling Decisions. // International Journal of Simulation Modelling. 13, 4(2013), pp. 213-224. DOI: 10.2507/IJSIMM12(4)1.237

[16] Wang, C.; Guan, Z.; Shao, X.; Ullah, S. Simulation-based optimisation of logistics distribution system for an assembly line with path constraints. // International Journal of Production Research. 52, 12(2014), pp. 3538-3551. DOI: 10.1080/00207543.2013.874602
[17] Usubamatov, R.; Alsalameh, A. A.; Ahmad, R.; Riza, A. R. Analysis of buffered assembly line productivity. // Assembly Automation. 34, 1(2014), pp 34-40. DOI: 10.1108/AA-11-2012-086

[18] Dordevic, M. S.; Zrnic, N. D.; Milicevic, M. R.; Miskovic, V. V. Information and material flow modeling in system of parts regeneration in multi-level supply system. // Technical Gazette. 20, 5(2013), pp. 861-869.

[19] Berlec, T.; Kusar, J.; Zerovnik, J.; Starbek, M. Optimization of a Product Batch Quantity. // Journal of Mechanical Engineering. 60, 1(2014), pp. 35-42. DOI: 10.5545/sv-jme.2013.1009

[20] Liu, S.; Gong, D. Modelling and Simulation on Recycling of Electric Vehicle Batteries - Using Agent Approach. // International Journal of Simulation Modelling. 13, 1(2014), pp 79-92. DOI: 10.2507/IJSIMM13(1)CO1

[21] Yang, Q.; Wu, D. L.; Zhu, H. M.; Bao, J. S.; Wei, Z. H. Assembly operation process planning by mapping a virtual assembly simulation to real operation. // Computers in Industry. $\quad 64, \quad 7(2013), \quad$ pp. 869-879. DOI: 10.1016/j.compind.2013.06.001

[22] Buchmeister, B.; Friscic, D.; Palcic, I. Impact of demand changes and supply chain's level constraints on bullwhip effect. // Advances in Production Engineering \& Management. 8, 4(2013), pp. 199-208. DOI: 10.14743/apem2013.4.167

[23] Venkata Rao, R.; Kalyankar, V. D. Optimization of modern machining processes using advanced optimization techniques: a review. // The International Journal of Advanced Manufacturing Technology. 73, 5-8(2014), pp. 1159-1188.

[24] Scap, D.; Hoic, M.; Jokic, A. Determination of the Pareto Frontier for Multi-Objective Optimization Problem. // Transactions of FAMENA. 37, 2(2013), pp. 15-28.

[25] Jayaswal, S.; Agarwal, P. Balancing U-shaped assembly lines with resource dependent task times: A Simulated Annealing approach. // Journal of Manufacturing Systems. 33, 4(2014), pp. 522-534. DOI: 10.1016/j.jmsy.2014.05.002

[26] Cevikcan, E. A Mathematical Programming Approach for Walking-worker Assembly Systems. // Assembly Automation. 34, 1(2014), pp. 56-68. DOI: 10.1108/AA-072013-067

[27] Pitiota, P.; Aldanondo, M.; Vareilles, E.Concurrent product configuration and process planning: Some optimization experimental results. // Computers in Industry. 65, 4(2014), pp. 610-621. DOI: 10.1016/j.compind.2014.01.012

[28] Gagliardi, J.-P.; Renaud, J.; Ruiz, A. A simulation modeling framework for multiple-aisle automated storage and retrieval systems. // Journal of Intelligent Manufacturing. 25, 1(2014), pp. 193-207. DOI: 10.1007/s10845-012-0686-x

[29] Jovanovic, V.; Stevanov, B.; Dudic, S.; Seslija, D.; Tesic, Z. Energy Efficiency Optimization of Air Supply System in a Water Bottle Manufacturing System. // Journal of Cleaner Production. $\quad 85, \quad$ (2014), pp. 306-317. DOI: 10.1016/j.jclepro.2014.03.021

[30] Ullah, H. A Petri net model for the integration of purchasing, production and packaging using Kanban system. // Advances in Production Engineering \& Management. 9, 4(2014), pp. 187-200. DOI: 10.14743/apem2014.4.187

[31] Piatkowski, T.; Sempruch, J.; Tomaszewski, T. Dynamics of a sorting process with a stream of discrete impact loads. // Transactions of the Canadian Society for Mechanical Engineering.38, 1(2014), pp. 139-154.

[32] Debevec, M.; Simic, M.; Herakovic, N. Virtual Factory as an Advanced Approach for Production Process Optimization. // International Journal of Simulation Modelling. 13, 1(2014), pp 66-78. DOI: 10.2507/IJSIMM13(1)6.260 
[33] Robinson, S.; Worthington, C.; Burgess, N.; Radnor, Z. J. Facilitated modelling with discrete-event simulation: Reality or myth? // European Journal of Operational Research. 234, 1(2014), pp. 231-240. DOl: 10.1016/j.ejor.2012.12.024

[34] Furtakova, S.; Figa, S.; Gregor, M. Simulation of Manufacturing and Logistics Systems for the 21th Century. // Applied Computer Science. 8, 1(2012), pp. 45-57.

[35] Chryssolouris, G.; Mavrikios, D.; Papakostas, N.; Mourtzis, D.; Michalos, G.; Georgoulias, K. Digital manufacturing: history, perspectives, and outlook. // Proceedings of the Institution of Mechanical Engineers, Part B: Journal of Engineering Manufacture. 223, 5(2009), pp. 451-462. DOI: 10.1243/09544054JEM1241

[36] Wenzel, S.; Jessen, U.; Bernhard, J. Classification and conventions structure the handling of models within the Digital Factory. // Computers in Industry. 56, 4(2005), pp. 334-346. DOI: 10.1016/j.compind.2005.01.006

[37] Savarese, A. B. Manufacturing Engineering. Nova Science Publishers, Inc., New York, 2011.

[38] Chofreh, A. G.; Goni, F. A.; Shaharoun, A. M.; Ismail, S.; Klemes, J. J. Sustainable Enterprise Resource Planning: Imperatives and Research Directions. // Journal of Cleaner Production.71, (2014), pp. 139-147. DOl: 10.1016/j.jclepro.2014.01.010

[39] Demaine, E. D.; Ghodsi, M.; Hajiaghayi, M. T.; SayediRoshkhar, A. S.; Zadimoghaddam, M. Scheduling to minimize gaps and power consumption. // Journal of Scheduling. 16, 2(2013), pp. 151-160. DOI: 10.1007/s10951012-0309-6

[40] Stankovski, S.; Lazarevic, M.; Ostojic, G.; Cosic, I.; Puric, R. RFID Technology in Product/Part Tracking During the Whole Life Cycle. // Assembly Automation. 29, 4(2009), pp. 364-370. DOI: 10.1108/01445150910987781

[41] Ostojic, G.; Stankovski, S.; Vukelic, D.; Lazarevic, M.; Hodolic, J.; Tadic, B.; Odri,S. Implementation of automatic identification technology in a process of fixture assembly/disassembly. // Journal of Mechanical Engineering. 57, 11(2011), pp. 819-825. DOI: 10.5545/svjme.2010.131

[42] Popescu, D.; Iacob, R. Disassembly method based on connection interface and mobility operator concepts. // International Journal of Advanced Manufacturing Technology.69, 5-8(2013), pp. 1511-1525.

[43] Shrouf, F.; Ordieres-Mere, J.; Garcia-Sanchez, A.; OrtegaMier, M. Optimizing the production scheduling of a single machine to minimize total energy consumption costs. // Journal of Cleaner Production.67, (2014), pp. 197-207. DOI: 10.1016/j.jclepro.2013.12.024

[44] Tecnomatix Plant Simulation. http://www.plm.automation.siemens.com/en_us/products/te cnomatix/plant_design/plant_simulation.shtml (19.01.2015)

[45] Semanco, P.; Marton, D. Simulation Tools Evaluation using Theoretical Manufacturing Model. // Acta Polytechnica Hungarica. 10, 2(2013), pp. 193-204.

[46] Bangsow, S. Manufacturing simulation with Plant Simulation and Simtalk: Usage and Programming with Examples and Solutions. Heidelberg: Springer, Berlin, 2010. DOI: $10.1007 / 978-3-642-05074-9$

\section{Authors' addresses}

Mihael Debevec, Ph.D.

University of Ljubljana, Faculty of Mechanical Engineering, Askerceva 6, SI-1000 Ljubljana, Slovenia

E-mail: miha.debevec@fs.uni-lj.si

Miha Pipan, Ph.D. candidate

University of Ljubljana, Faculty of Mechanical Engineering, Askerceva 6, SI-1000 Ljubljana, Slovenia

E-mail: miha.pipan@fs.uni-lj.si

Hugo Zupan, Ph.D. candidate

University of Ljubljana, Faculty of Mechanical Engineering, Askerceva 6, SI-1000 Ljubljana, Slovenia E-mail: zupan.hugo@gmail.com

Niko Herakovic, Ph.D., Associate professor

University of Ljubljana, Faculty of Mechanical Engineering, Askerceva 6, SI-1000 Ljubljana, Slovenia

E-mail: niko.herakovic@fs.uni-lj.si 